\title{
EXPERIMENT: IMPROVE THE FOREARM PASS SKILL OF VOLLEYBALL THROUGH PAIR TRAINING
}

\author{
Zainur \\ Correspondence: University of Riau, Pekanbaru, Indonesia \\ E-mail: zainur@lecturer.unri.ac.id
}

\begin{abstract}
Abstrak
Penelitian ini bertujuan untuk mengetahui peningkatan keterampilan passing bawah atlet bolavoli melalui latihan berpasangan. Populasi dalam penelitian ini adalah atlet bolavoli MVC (Mufakat Volly Club) Pekanbaru yang berjumlah sebanyak 12 orang. Sampel menggunakan teknik total sampling sehingga sampel berjumlah 12 orang. Instrumen dalam penelitian ini adalah tes keterampilan passing bawah bolavoli. Teknik analisis data menggunakan uji t. Berdasarkan analisis data dan pembahasan, dapat disimpulkan bahwa terdapat peningkatan keterampilan passing bawah atlet bolavoli MVC (Mufakat Volly Club) Pekanbaru melalui latihan berpasangan terbukti dengan hasil thitung $4,024>t_{\text {tabel }} 1.796$ pada $\alpha=0,05$.
\end{abstract}

Kata Kunci: Latihan, Berpasangan, Keterampilan, Passing, Bolavoli

Abstract
This research aimed to know the increase in the skills of forearm pass volleyball athletes through the exercises in pairs. The population was the athletes of volleyball MVC (Consensus Volly Club) Pekanbaru that amounted to as many as 12 people. The sample used the technique of total sampling so that the amount of sample was 12 people; i The instrument in this study was a test forearm pass: volleyball. Analysis techniques used test t. Based on the data analysis and discussion, it could be concluded that the improvement of the skills of forearm pass volleyball athletes MVC (Consensus Volly Club) Pekanbaru through pairing exercises with proven results tcalculate 4,024> ttable 1,796 at $\alpha=$ 0.05 .

\section{Keywords: Exercise, Pairs, Skills, Passing, Volleyball}

\section{Introduction}

Sport is a systematic activity to encourage, foster, and develop physical, spiritual and social potential. Syafruddin, (2011) sports achievement that is "sports that foster and develop sportsman in a planned, tiered and sustainable manner through training and competition to achieve achievement with the support of sports science and technology". Gazali (2016) in achievement sports there are several supporting aspects that must be possessed by each player in order to 
perform well, these supporting aspects include: technical ability, physical condition, tactics and strategy, as well as mental and psychological aspects.

One of sports which is the concern to researcher is volleyball. Volleyball is a branch of team game sports, played by two teams, each of which consists of six players, Satria (2019). The aim of the players in playing volleyball is to drop the ball as fast as possible on the opponent's pitch over the net with the body of the waist up with the condition that the ball bounces perfectly in accordance with the rules, Muttaqin et al in Candra \& Henjilito (2018).

The game of volleyball is not easy to be done by everyone, because in the game of volleyball it takes coordination of motion that is really reliable to do all the movements that exist in the game of volleyball. The game of volleyball is very fast developing and one of the sports is very popular in Indonesia after soccer and badminton. The popularity of this sport can be seen from the field facilities in rural and urban areas and various activities held in championships between schools, between agencies, between companies, and others.

In volleyball games, there are some basic techniques which must be mastered by a player. Gazali (2016) basic techniques in the volleyball game include service, passing, smash, and block. Mastery of motion skills is very important in volleyball games, if mastery of motion is good and right in accordance with basic techniques, it will get the desired results, Abrasyi, Hernawan, Sujiono, \& Dupri (2018). From some of these basic techniques, passing is a basic technique that must be trained and learned.

Passing is often called back pass and assist the ball to a friend. Passing in a volleyball game is a person's volleyball effort and uses certain techniques to pass the ball played to his teammates. Passing consists of forearm pass and passing up. In this study the discussion focuses on the basic techniques of forearm pass volleyball, beeause in the game of volleyball, the very basic thing is mastery of forearm pass. Almost all aspects such as receiving the first ball, passing, and holding the opponent's spike really need this skill, Sukarya, Wa'asil, \& Nurfalah (2018).

Forearm pass the volleyball is a technique in the game of volleyball whose goal is to pass the ball to a place or to a friend of his own in a team, to further play back and can also be said as the first step to compile the pattern of attacks on the opposing team. In addition to passing, under passing is useful to withstand attacks from opponents. Syarifah (2016) Forearm pass specifically is done in an effort to resist all types of attacks launched by the opposing team in the form of passing, smash, tip and so forth. Generally attacks launched by opponents when playing are hard, heavy and fast. Therefore, one effective effort to withstand attacks is to use forearm pass. If a player cannot receive the service properly and correctly then the points will be added to the opposing team, Chan \& Indrayeni (2018).

To increase mastery in volleyball games it is necessary to have maximum and systematic training in order to create maximum results. One of them is with pair training. Destriana (2018) stated that in an exercise must be done repeatedly by increasing resistance (load) in order to increase the strength and endurance of 
the muscles needed. Based on the above, the researcher would like to see an increase in forearm passing skills of the volleyball athletes by providing pair passing exercises.

\section{Method}

This research site was conducted at the MVC Volleyball Club Pekanbaru. Because the research used one group, this research used a one-group pretest-post test design approach. In this design there was a pretest before being given treatment. Thus, the results of the treatment were known more accurately, because it compared with the conditions before being given treatment.

The population in this study was the MVC (Mufakat Volly Club) Pekanbaru volleyball athletes, amounting to 12 people. In this study the sampling technique was carried out by means of total sampling of a total of 12 athletes.

Research data collection techniques and tools used the skill of forearm passing volleyball test. While the data analysis technique used the mean different test analysis technique ( $\mathrm{t}$ test). Before testing the hypothesis, the researcher firstly conducted the testing of analysis requirements with the Lilliefors normality test.

\section{Discussion}

The results of the study were described in accordance with the objectives of the hypothesis proposed earlier.

\section{a. Pre Test}

Based on an analysis of preliminary test data, an increase in forearm passing skills of the MVC (Mufakat Volly Club) Pekanbaru volleyball athletes by giving paired passing exercises shows the following results: the highest score of 11 and the lowest score of 3 with an average of 7.25 and a standard deviation of 2,53 , the complete distribution of data was made distribution table as follows:

\begin{tabular}{llll}
\multicolumn{5}{c}{$\begin{array}{l}\text { Was made distribution table as follows: } \\
\text { No }\end{array}$} & Table 1. Distribution of Pre-Test Passing Frequencies below \\
\hline \multirow{2}{*}{ Interval Class } & Frequency & \\
\cline { 3 - 4 } & $3-4$ & 1 & Rbsolute \\
\hline 2 & $5-6$ & 4 & 8,33 \\
\hline 3 & $7-8$ & 3 & 33,33 \\
\hline 4 & $9-10$ & 2 & 16,67 \\
\hline 5 & $11-12$ & 2 & 16,67 \\
\hline Total & & $\mathbf{1 2}$ & $\mathbf{1 0 0} \%$ \\
\hline
\end{tabular}

Based on the frequency distribution table above from 12 samples, it turns out as many as 1 person (8.33\%) with a range of intervals $3-4$, then 4 people $(33.33 \%)$ with a range of intervals $5-6$, while 3 people $(25 \%)$ with a range of intervals of $7-8$, then 2 people $(16.67 \%)$ with an interval of $9-10$, and 2 people $(16.67 \%)$ with an interval of 11-12, for more details can be seen in the histogram below : 


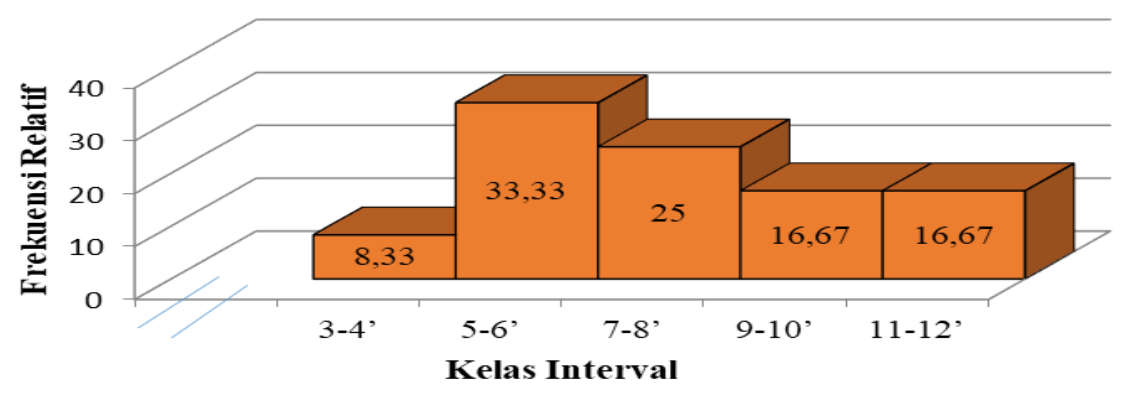

Figure 1. Histogram Pre Test of Forearm Pass

\section{b. Post Test}

Based on the analysis of the final test data, an increase in forearm pass skills the MVC (Mufakat Volly Club) Pekanbaru volleyball athletes by giving paired passing exercises showed the following results: highest score of 19 and lowest 5 with an average of 10.08 and standard deviation of 5.38. For more details, the frequency distribution can be made as follows:

Table 2. Distribution of Post Passing Lower Frequency

\begin{tabular}{llll}
\hline \multirow{2}{*}{ No } & \multirow{2}{*}{ Interval Class } & Frequency & \\
\cline { 3 - 4 } & & Absolute & Relative (\%) \\
\hline 1 & $5-7^{\prime}$ & 6 & 50 \\
\hline 2 & $8-10$ & 2 & 16,67 \\
\hline 3 & $11-13^{\prime}$ & 1 & 8,33 \\
\hline 4 & $14-16$ & 0 & 0 \\
\hline 5 & $17-19$ & 3 & 25 \\
\hline Jumlah & & $\mathbf{1 2}$ & $\mathbf{1 0 0} \%$ \\
\hline
\end{tabular}

Journal Physical Education. Health and Recreation.

Based on the above frequency distribution table from 12 samples, it turned out that as many as 6 people (50\%) with a range of 5-7 intervals, then 2 people $(16.67 \%)$ with a range of $8-10$ intervals, while 1 person $(8.33 \%)$ with a range of intervals $11-13$, then 3 people (25\%) with a range of intervals $17-19$, and range of intervals of 14-16 no, for more details can be seen in the histogram:

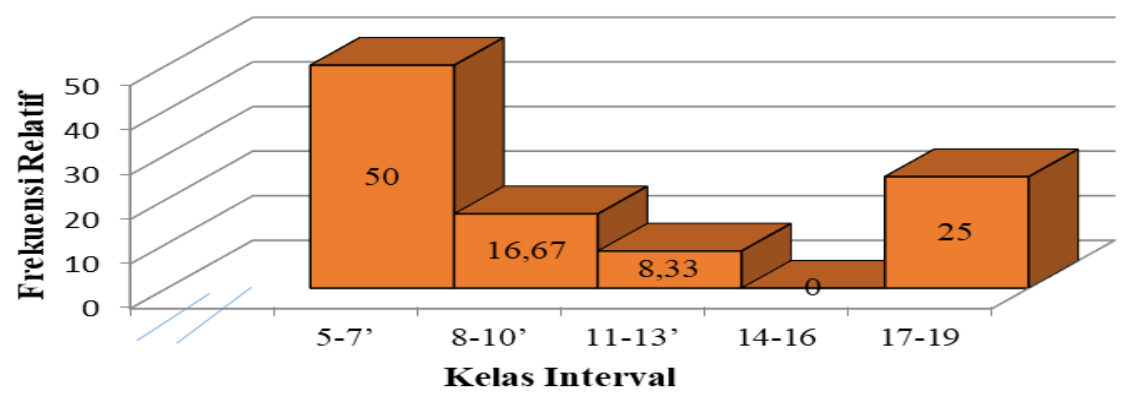

Figure 2. Histogram Pre Test of Forearm Pass

PJKR

http://jurnal.unimed.ac.id/2012/index.php/jpehr 
c. Testing Requirements Analysis with Lilliefors Test

Analysis of normal test data was carried out using the Liliefors test. The results of the normal test analysis of each variable were presented in the form of a table below, and the calculation of the results can be seen in the appendix.

Table 3. Test Data Normality With Lilliefors Test

\begin{tabular}{lllll}
\hline No & Variable & Lo & Lt & Remarks \\
\hline 1 & Forearm Pass Training (Initial) & 0.147 & \multirow{2}{*}{0.242} & Normal \\
\hline 2 & Forearm Pass Training (Final) & 0.216 & & Normal \\
\hline
\end{tabular}

In the table above it can be seen that the results of Lo are smaller than Lt, it can be concluded that the data are normally distributed.

d. Hypothesis testing

To test whether the hypothesis proposed in this study was accepted or not, the data testing using the bound sample $t$ test was performed. From the analysis conducted, the t-test value between the initial test and the final test of the Forearm pass exercise under the ability of forearm pass showed the value of 4.024 and then compared with the value of the table at a significant level of 0.05 degrees of freedom N-1 (11) turned out to show the number 1,796, $\mathrm{p}$ this showed that the value of tcount (4.024)> ttable (1.796), it can be concluded that the hypothesis that there was an increase in passing skills under the MVC (Mufakat Volly Club) Pekanbaru volleyball athletes by providing pair passing training.

Some form of exercise was done to improve forearm pass skills. One of them was by using forearm passing of pair training. From the research conducted there was an increase, this could be seen from the pretest before doing the training in the medium category, after doing the training it increased to be sufficient with a frequency of 17-19. This increase was also seen in the average player before doing the exercise on average 7.25 , whereas after training the average increased to 10.08. It was seen that this exercise was done to improve forearm pass skills.

Another improvement could be seen from the research process conducted on 12 samples. Before the exercise was done, before the pre test or initial test was done then the exercise wass done, the end of the exercise was taken the post test data or the final results. After the data collected, it was then analyzed using a statistical formula to find out whether there was an influence or not.

Based on the analysis carried out, the value of t-counts between the initial test and the final test of forearm pass practice on the ability of forearm pass showed a figure of 4.024. Furthermore, the value obtained compared with the table at a significant level of 0.05 with degrees of 
freedom $\mathrm{N}-1$ (11) turned out that the value obtained was 1.796, this showed that the value of tcount (4.024)> ttable (1.796) thus it was concluded that the hypothesis stating there was an increase in forearm pass skills of the MVC (Mufakat Volly Club) Pekanbaru volleyball athletes by providing pair passing training.

From the analysis it can also be concluded that there is an effect of paired underhand training on increasing forearm pass skills. Programmed and continuous training, the more routine we conducted pair training of frearm pass, the better the forearm pass skills under the team.

Based on the above it was clear that to get the results of forearm pass skills, it can be improved by doing pair training of forearm pass. This was seen from the results obtained that by using the forearm pass exercises, the results of the forearm pass skills were also increased, especially in the MVC (Mufakat Volly Club) Pekanbaru athletes who already held this research.

There were a number of obstacles when conducting research such as lack of researcher control over athletes, so there was a little lack of training which was not very good implementation. Then there were several times the implementation of the weather was not supportive, wind or rain, while we continued to carry out the exercise, which resulted in less than optimal training. Furthermore, in this study, researchers could only control from the field and could not control what was done outside of research activities, such as doing other exercises outside or eating food that was not recommended during exercise.

From previous studies that have been studied by Rahmat \& Wahidi (2018) concluded that there was an influence of learning passing through pairing guidance on the passing skills in volleyball. Awaluddin (2016) stated the results of passing under volleyball skills through the application of paired passing training methods were better than the unpaired passing training method. Rahmat \& Wahidi (2018) stated that learning to pass in pairs could improve hand and foot coordination, increase strength and flexibility of hand muscles, increase agility in receiving and passing the ball and improve the skill of forearm pass in the game of volleyball. From the three studies, it could be said that paired training can increase forearm pass of volleyball.

\section{Conclusion}

Based on data analysis and discussion, it was concluded that there was an increase in forearm pass skills of the MVC Volleyball (Pekanbaru Volunteer) athletes through paired training as evidenced by the results of tcount of $4.024>$ t table 1.796 at $\alpha=0.05$.

\section{References}

Abrasyi, R., Hernawan, Sujiono, B., \& Dupri, 2018. Model Latihan Passing 
Bawah Bola Voli Pada Siswa Sekolah Menengah Pertama. Journal Sport Area. Volume: 3, Edisi: 2: 168-178.

Awaluddin, 2016. Perbedaan Pengaruh Metode Latihan Passing Berpasangan dan Metode Latihan Passing Tidak Berpasangan Terhadap Keterampilan Passing Bawah Bolavoli Ditinjau Dari Kekuatan Lengan Siswa SMP Kartika XX_2 Wirabuana Makassar. Jurnal Penjaskesrek STKIP Mega Rezky Makassar. Volume: 1, Edisi: 2: 1-14.

Candra, A., \& Henjilito, R, 2018. Pengaruh Latihan Pukulan Menggunakan Imagery Terhadap Hasil Smash permainan Bolavoli. Journal Sport Area. Volume: 3, Edisi: 2: 102-110.

Chan, F., \& Indrayeni, Y, 2018. Meningkatkan Kemampuan Passing Bawah Dalam Permainan Bola Voli Melalui Pendekatan TGFU Pada Siswi Kelas VIII SMP Negeri 11 Muaro Jambi. Journal Physical Education, Health and Recreation. Volume: 2, Edisi: 2: 186-197.

Destriana, 2018. Latihan Pasing Atas Double Contact terhadap Keterampilan Bola Voli. Altius: Jurnal Ilmu Olahraga dan Kesehatan. Volume: 7, Edisi: 1: 24-32.

Gazali, N, 2016. Kontribusi Kekuatan Otot Lengan Tehadap Kemampuan Servis Atas Atlet Bolavoli. Journal of Physical Education, Sport, Health and Recreations. Volume: 3, Edisi: 1: 1-6.

Gazali, N, 2016. Pengaruh Metode Kooperatif dan Komando Terhadap Keterampilan Teknik Dasar Bermain Sepakbola. Journal Sport Area. Volume: 1, Edisi: 1: 56-62.

Rahmat, D., \& Wahidi, R, 2018. Pengaruh Pembelajaran Passing Berpasangan Terhadap Keterampilan Passing Bawah Dalam Permainan Bola Voli. JUARA: Jurnal Olahraga. Volume: 3, Edisi: 2: 96-103.

Satria, M. H, 2019. Pengaruh Latihan Kekuatan Jari-Jari Tangan Terhadap Peningkatan Kemampuan Passing Atas Dalam Permainan Bola Voli. Journal Sport Area. Volume: 4, Edisi: 1: 230-239.

Sukarya,,Y., Wa'asil, F., \& Nurfalah, S, 2018. Peningkatan Pembelajaran Passing Bawah Dalam Permainan Bola Voli Dengan Metode Bermain Menggunakan Papan Pantul Pada Siswa Kelas VIII Sekolah Menengah Pertama Kristen Abdi Wacana Kota Pontianak. Journal Physical Education, Health and Recreation. Volume: 2, Edisi: 2: 169-180.

Syafruddin, 2011. Ilmu Kepelatihan Olahraga. Padang: UNP-Press.

Syarifah. 2016. Upaya meningkatkan hasil belajar passing bawah Bola Voli melalui variasi pembelajaran dan Media Audio Visual Di Kelas VIII A SMP Negeri 6 Padang Bolak Kabupaten Padang Lawas Utara Tahun Pelajaran 2013/2014. Journal Physical Education, Health and Recreation. Volume: 1, Edisi: 1: 21-33. 